can Widgeon, Shoveler. Redhead, Ring-necked Duck, Canvasback, Lesser Scaup, Common Goldeneye, Bufflehead, Ruddy Duck, Common Merganser, Cooper's Hawk, Red-tailed Hawk, Swainson's Hawk, Rough-legged Hawk, Marsh Hawk, Pigeon Hawk, Sparrow Hawk, Gray Partridge. Sandhill Crane, Sora, American Coot, Killdeer, Golden Plover, Black-bellied Plover, Ruddy Turnstone, Common Snipe, Spotted Sandpiper, Solitary Sandpiper, Willet, Lesser Yellowleg;, Knot, Ruff, Pectoral Sandpiper, White-rumped Sandpiper, Baird's Sandpiper, Least Sandpiper, Short-billed Dowitcher, Long-billed Dowituher, Stilt Sandpiper, Semipalmated Sandpiper, Buff-breasted Sandpiper, Marbled Godwit, Hudsonian Godwit, American Avocet, Wilson's Phalarope, Northern Phalarope, California Gull, Ring-billed Gull, Franklin's Gull, Common Tern, Black Tern, Rock Dove, Mourning Dove, Long-eared Owl, Common Nighthawk, Belted Kingfisher, Yellow-shafted Flicker, Yellow - bellied Sapsucker, Downy Woodpecker, Eastern Kingbird, Western Kingbird, Eastern Phoebe, Traill's Flycatcher, Least Flycatcher, Olive-sided Flycatcher, Horned Lark, Tree Swallow, Bank Swallow, Barn Swallow, Black-billed Magpie, Common
Crow, Red-brfasted Nuthatch, Brown Creeper, House Wren, Catbird, Brown Thrasher, Robin, Hermit Thrush, Swainson's Thrush, Graycheeked Thrush, Veery, Ruby-crowned Kinglet, Water Pipit, Sprague's pipit, Cedar Waxwing, Loggerhead Shrike, Starling, Red-eyed Vireo, Warbling Vireo, Black and-white Warbler, Tennessee Warbler, Orange-crowned Warbler, Yellow Warbler, Magnolia Warbler, Myrtle Warbler, Blackpoll Warbler, Palm Warbler, Ovenbird, Northern Waterthrush, Wilson's Warbler, American Redstart House Sparrow, Western Meadowlark, Yellow-headed Blackbird, Red-winged Blackbird, Baltimore Oriole, Rusty Blackbird. Brewer's B la ckbird, Common Grackle, Brown-headed Cowbird, Rose-breasted Grosbeak, Purple Finch, Pine Siskin, American Goldfinch, Rufous-sided Towhee, Savannah Sparrow, Baird's Sparrow, LeConte's Sparrow, Vesper Sparrow, Slate-colored Junco, Tree Sparrow, Chipping Sparrow, Clay-colored Sparrow, Harris' Sparrow, White-crowned Sparrow, White-throated Sparrow. Fox Sparrow, Lincoln's Sparrow, Song Sparrow, Lapland Longspur, Chestnut-collared Longspur, Snow Bunting.

\title{
THE GARGANEY, A NEW BIRD FOR MANITOBA
}

\section{by Rudolf F. Koes, 348 Oakwood Avenue, Winnipeg 13}

On May 23, 1971, my wife and I decided to join Winnipeg birdwatchers for the annual outing to St. Ambroise on the south shore of Lake Manitoba, approximately 60 miles northwest of Winnipeg.

Having arrived at the beach, we stopped to look at some waders and ducks feeding in a shallow, marshy pond on the south side of the wooded ridge along the lake. Several ducks were present, among them Blue-winged Teal, Pintail and Mallard. One other species of duck was preesnt, but it was so familiar I paid little attention to it. This was an adult drake Garganey (Anas querquedula), the size of a Blue-winged Teal and a duck common in my native Holland. After a moment, however, I made a quick check in our Birds of North America (Robbins, et al., 1966) and was surprised to find that the bird was not even listed for this continent.

Delacour (1956:163) gives the following description of the male Garganey in breeding plumage:

“. . a black crown and throat, broad, long white supercilia joining on the nape, and the rest of the head and neck brownish chestnut streaked with white; mantle, back and tail blackish brown with pale borders to the feathers; wings generally as in the other species of the group, the long, lanceolate, ornamental scapulars glossy black with a broad central white line, the wing coverts pale bluish grey, the mirror light green between two wide white bands; breast light brown laced with black; rest of underparts white, finely waved with black on the sides and spotted on the vent and undertail coverts. Iris brown; bill and legs leaden grey."

After observing the Garganey for about half an hour through 10 X 50 binoculars, we decided to alert the rest of the group. Luckily, several prominent ornithologists were present, among them Dr. Bob Nero and Herb Copland. All were able to see the bird several times. It was observed by close to a dozen persons from approximately $12: 30$ p.m. to $2: 00$ p.m., through binoculars $(10 \times 50,7 \times 50,8 \times 35$, etc.) and a 25-power telescope. The minimal viewing distance was about 100 feet. At the time the temperature was between $60^{\circ}$ and $65^{\circ} \mathrm{F}$. and it was mostly cloudy with little wind.

Dr. Bob Nero made the following 


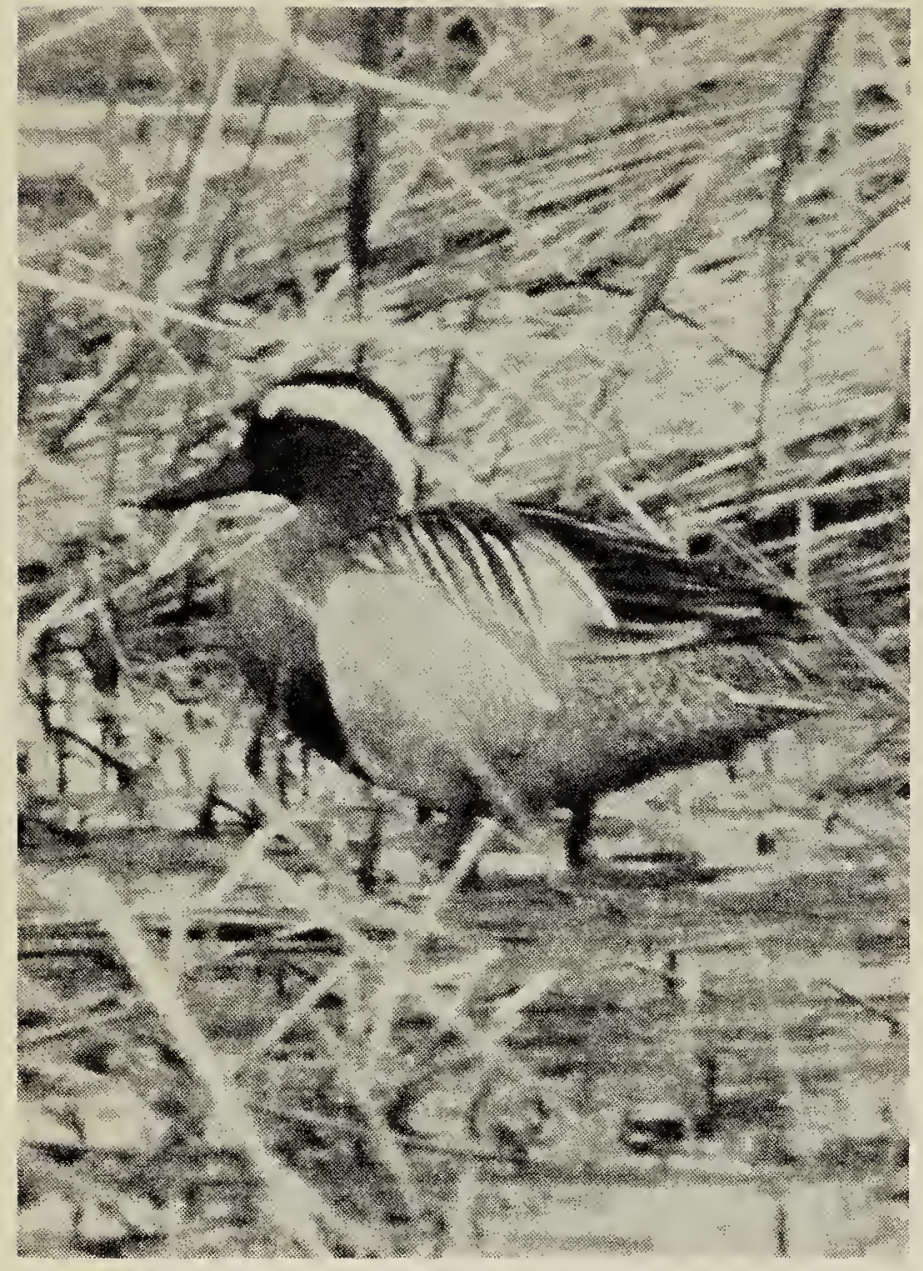

Garganey

Photo by Vere Hunt Scott

notes on the behaviour of the Garganey which was in constant company of a pair of Blue-winged Teal:

"The relationship of the Garganey to a pair of Blue-winged Teal with which it was associating was particularly interesting. It was attached to the female Blue-wing and repeatedly kept itself between the female and the drake Blue-wing. It also constantly fol. lowed the female Blue-wing. On a few occasions it made aggressive dashes and other signs of intolerance towards the male Blue-wing.

"The female Blue-wing, however, paid little attention to the Garganey, and several times she showed incitement display directed towards the male Blue-wing, bobbing her head in typical incitement behaviour and eliciting similar behavior from the male Blue-wing. The latter showed a surprising tolerance to the Garganey, permitting it to come between itself and its mate with little or no signs of aggression. And it also permitted the Garganey to swim beside its mate; other teal, however, at least male Blue-wings, were vigorously routed, sometimes even distant birds receiving this aggressive attention from the drake Blue-wing.

"In summary, the Garganey had a strong attachment to the hen of a mated (i.e., pair bond developed) pair of Blue-winged Teal, both of which were highly tolerant of the Garganey.

"On one flight, the Garganey was in the lead. This group consisted of the Garganey, the pair of Blue-winged Teal, and one or two other drake Bluewings."

At approximately 2:00 p.m. the bird flew away-still in company of the Bluewings - and was not seen until about 5:00 p.m. At that time Mr. Vere Scott was able to take a number of black and white photographs with a $400 \mathrm{~mm}$. telephoto lens.

The distribution of the Garganey, according to Delacour (p. 164) is as follows :

"Breeds in the British Isles and Iceland (rare), farther east, north to about $64^{\circ}$ in Sweden, central Finland, northern Russia (Karelia, Sovovetski Island, Archangel), western Siberia (Berezov on the Ob) ; eastern Siberia (Yenisei $60^{\circ}$, Lena $62^{\circ}$, northern shore of Lake Baikal, Amur River), Kamachatka and the Commander Islands, sporadic farther north; south to Spain (Quadalquivir, Marismas), southern France (Camargue), central Italy, Albania, Bulgaria, Crimea, Transcau. casia, Turkestan to Altai, Semepalatinsk, Tarbagatai, Mongolia and Manchuria; occasionally in Sardinia, Tunisia, Cyprus and Naxos. Winters in southern Europe, Africa, south to the Congo and Nyasaland, the Seychelles, southern Asia, Malaysia, the Philippines, Celebes, Moluccas, New Guinea; stragglers in Australia."

Fisher (1967: plate 14) notes that the bird is highly migratory.

Although the species is not listed by Godfrey (1966) there is one previous record for Canada. On June 22, 23 and 24,1961 , an adult drake Garganey was seen near Two Hills, Alberta, by Lawson G. Sugden and Ronald H. Mackey 
(Sugden, 1963). Sugden assumed that this bird had escaped captivity and migrated north from some western U.S. zoo.

Because of the possibility that the Manitoba bird had escaped from a zoo or private collection I contacted $\mathrm{Mr}$. J. C. Shaver of the Canadian Wildlife Service in Edmonton, who advised me (pers. corres., June 7, 1971) that he was not aware of any person or zoo in western Canada in possession of live Garganeys.

Mr. Chandler, S. Robbins, Chief of Migratory Non-Game Bird Studies in the U.S.A. (pers. corres., July 29, 1971) notes as follows:

"Mr. Glen Smart of our Endangered Species Program estimates that there are somewhere in the vicinity of 200 Garganeys in captivity in North America. Some waterfowl escape into the wild every year and losses occasionally are very heavy (as during the hurricane season along the south Atlantic coast).... many of the birds are lost without their absence being detected by the owner, and failure to secure documentation of escapes does not mean that escapes into the wild have not occurred. There have been a few reports of Garganeys in the wild in the Middle Atlanic States, and it is quite likely that some of these birds migrate to Manitoba. We have been forced to assume that all such birds have been in captivity."

Although it is not possible to show that the Garganey was a true immigrant to this continent, it is quite conceivable considering the fact that its breeding range in two places almost touches North America and that the Garganey is highly migratory.

\section{LITERATURE CITED}

Delacour, J. 1956. The waterfowl of the world. Vol. 2, London.

Fisher, J. 1967. Thorburn's birds. London.

Godfrey. W. E. 1966. The birds of Canada. Natl.. Mus. Can. Bull. No. 203, Ottawa. $428 \mathrm{pp}$.

Robbins, C. S., B. Bruun, and H. S. Zim. 1966. Birds of North America. Golden Press, New York.

Sugden, L. G. 1963. A Garganey duck in the wild in Alberta. Blue Jay, 21:4-5.

\title{
FIRST RECORDED TURKEY VULTURE NEST IN RIDING MOUNTAIN NATIONAL PARK, MANITOBA
}

\author{
by E. W. Andrusiak, D. C. Harbottle and K. R. Whaley \\ Riding Mountain National Park, Wasagaming, Manitoba
}

The Turkey Vulture (Cathartes (uura) is listed as an "occasional casual visitor" in Riding Mountain National Park by Taverner and Sutton $(1940: 4)$. Soper $(1953: 15)$ did not observe this species during his faunal investigations in the park from 1940 to 1946. Godfrey $(1953: 8)$ did not mention any Riding Mountain records although observations from Duck Mountain and Dauphin, to the north of the park, are listed. Godfrey (1966: 85) also reported nests on the Duck Mountain, on Elk Island in Lake Winnipeg, and at Long Lake north of Whiteshell Provincial Park. Long (1971) reported 12 known nests from Saskatchewan, including Madge Lake on the Duck Mountain. Blood (1964: 204) listed seven observations between
June 15 and October 20, 1962 and three observations between May 4 and September 17, 1963, including several pairs, at Riding Mountain. Since the latter observations there have been numerous sightings of Turkey Vultures in Riding Mountain National Park by the warden and naturalist staff.

On June 2, 1971 a nest was located on a fairly large island at the north end of Baldy Lake. Baldy Lake is 16 miles north of Oakburn, Manitoba and 2 miles within the park boundary. A vulture was first sighted from a fire tower which overlooks the lake at its south end. It circled the lake and disappeared. Upon investigation of the main islands in the lake this or another vulture was flushed from the nest. 